\title{
Convergence of a diabetes mellitus, protein energy malnutrition, and TB epidemic: the neglected elderly population
}

Sonia Menon ${ }^{1,2^{*}}$, Rodolfo Rossi ${ }^{3}$, Leon Nshimyumukiza ${ }^{4}$, Aibibula Wusiman ${ }^{5}$, Natasha Zdraveska ${ }^{6}$ and Manal Shams Eldin ${ }^{7}$

\begin{abstract}
Background: On a global scale, nearly two billion persons are infected with Mycobacterium tuberculosis. From this vast reservoir of latent tuberculosis (TB) infection, a substantial number will develop active TB during their lifetime, with some being able to transmit TB or Multi-drug- resistant (MDR) TB to others. There is clinical evidence pointing to a higher prevalence of infectious diseases including TB among individuals with Diabetes Mellitus (DM). Furthermore, ageing and diabetes mellitus may further aggravate protein-energy malnutrition (PEM), which in turn impairs Tlymphocyte mediated immunologic defenses, thereby increasing the risk of developing active TB and compromising TB treatment. This article aims to a) highlight synergistic mechanisms associated with immunosenescence, DM and PEM in relation to the development of active TB and b) identify nutritional, clinical and epidemiological research gaps.
\end{abstract}

Methods: To explore the synergistic relationship between ageing, DM, tuberculosis and PEM, a comprehensive review was undertaken. The MEDLINE and the Google Scholar databases were searched for articles published from 1990 to March 2015, using different MESH keywords in various combinations.

Results: Ageing and DM act synergistically to reduce levels of interferon gamma (IFN- $\gamma$ ), thereby increasing susceptibility to TB, for which cell mediated immunity (CMI) plays an instrumental role. These processes can set in motion a vicious nutritional cycle which can predispose to PEM, further impairing the CMI and consequently limiting host defenses. This ultimately transforms the latent TB infection into active disease. A clinical diagnostic algorithm and clinical guidelines need to be established for this population.

Conclusion: Given the increase in ageing population with DM and PEM, especially in resource-poor settings, these synergistic tripartite interactions must be examined if a burgeoning TB epidemic is to be averted. Implementation of a comprehensive, all-encompassing approach to curb transmission is clearly indicated. To this end, clinical, nutritional and epidemiological research gaps must be addressed without a delay.

\section{Background}

TB infection occurs when a susceptible person inhales droplets containing Mycobacterium tuberculosis bacteria, which travel through the respiratory tract to the alveoli. In most patients, host's immune response limits the propagation of TB infection, resulting in an asymptomatic, non-transmissible localized infection that may remain in the body for many years, if not forever.

\footnotetext{
* Correspondence: soniasimonemenon@gmail.com

${ }^{1}$ International Centre for Reproductive health, Ghent University, LSHTM Alumni, Ghent, Belgium

${ }^{2}$ CDC Foundation, Atlanta, USA

Full list of author information is available at the end of the article
}

One in three people in the world has latent tuberculosis [1]. In 2009, approximately 9 million new cases of active TB were diagnosed and 1.7 million persons succumbed to the disease [2]. An additional challenge to TB control efforts is the global increase in multi-drug resistant TB (MDR-TB), defined as TB caused by strains resistant to at least isoniazid and rifampin. In 2013, the World Health Organization (WHO) reported that $3.6 \%$ of the new cases and $20.2 \%$ of the previously treated cases had MDR-TB [3].

Concurrently, diabetes mellitus (DM) is burgeoning as a worldwide chronic health condition, which can be attributed to increases in obesity, changing patterns of 
diet and physical activity as well as ageing $[4,5]$. According to WHO estimates, there are currently 347 million people worldwide affected by DM, [6] and by 2030 its prevalence is projected to increase by $50 \%$ [6]. 3/4 of diabetic patients live in low-income countries [7-9]. It is now well-established that cellular immune responses mediated by $\mathrm{T}$ cells and macrophages play a major role in the defense against TB [10]. In particular, the Th1 cytokine interferon (IFN)- $\gamma$ is considered a principal mediator of protective immunity against TB $[11,12]$

DM is a clinical syndrome associated with deficiency of insulin secretion or resistance to its actions. Apart from the classical micro and macrovascular complications of the disease, DM has been associated with reduced $\mathrm{T}$ cell response and neutrophil functional activity as well as humoral immunity disorders, $[13,14]$ which in turn compromises the protective role that cellular immune response plays against TB. Consequently, DM patients show increased susceptibility to infections, notably $\mathrm{TB}$, compared to individuals without $\mathrm{DM}[2,15]$.

Some studies have shown that TB/DM comorbidity is common, both in low-income and high-income countries. [2, 16]. A 2008 systematic review of literature which identified 13 age-adjusted, quantitative, observational studies in North America, UK, Russia, Mexico, Korea, Taiwan and India reported a relative risk of TB in DM patients of 3.1 in cohort studies, with odds ratios ranging from 1.16 to 7.83 in case control studies [17]. An epidemiological model indicated that in India DM might account for nearly $15 \%$ of pulmonary tuberculosis (PTB) cases [18].

In diabetic patients, pulmonary TB may progress rapidly and hence requires a high index of suspicion in the diagnostic phase [19].

Furthermore, the rising number of ageing diabetic population at risk for TB represents a worldwide health threat. People aged 60 and older make up over $11 \%$ of the global population and by 2050 that number is expected to rise to about $22 \%$ [20]. By 2050, 4 out of 5 people over 60 will live in developing countries [21]. In this population group, approximately $90 \%$ of TB cases are due to reactivation of primary infection [22].

Ageing is associated with a decline in T cell proliferation and reduced synthesis of interferon gamma (IFN- $\gamma$ ), [23] which compromises body's protective defenses against TB. In turn, by compounding the decrease in IFN $-\gamma$ DM predisposes the ageing patient to infections where cell-mediated immunity plays a pivotal role, such as tuberculosis.

Moreover, ageing and DM act synergistically and further aggravate protein-energy malnutrition (PEM), which is common in chronic disease states and is associated with increased morbidity and mortality [24]. This tripartite interaction additionally impairs T-lymphocyte mediated immunologic defenses, increasing the risk of certain infectious diseases [25]. According to the WHO, the number of people with TB attributable to PEM may exceed the number of people whose TB develops secondary to HIV infection, smoking or DM [26]. The negative impact of undernutrition on cell-mediated immunity is well documented [25, 27-29]. Malnutrition and infection interact with each other synergistically. Recurrent TB may cause loss of body nitrogen and worsened nutritional status. The resulting malnutrition may in turn increase the susceptibility to recurrent infection.

Using data from existing literature, this article aims to highlight the synergistic mechanisms associated with immunosenescence and DM in relation to development of active TB. This includes the possible association between ageing and development of TB and/or PEM and the possible association between TB and PEM. The possibility of treatment for latent TB in the ageing population with DM is also explored.

Finally, this paper aims to identify the clinical and epidemiological research gaps which need to be addressed in order to curb transmission.

\section{Method}

To explore the synergistic relationship between ageing, DM, tuberculosis and PEM, the MEDLINE and the Google Scholar databases were searched for articles published from 1960 to March 2015. The following keywords were identified using medical subject headings and truncations:

\section{Synergistic biological mechanisms between DM, ageing TB population and PEM Ageing and TB}

("ageing"[MeSH Terms] OR "ageing"[All Fields]) AND ("tuberculosis"[MeSH Terms] OR "tuberculosis"[All Fields]) yields 523 results

\section{Ageing and DM}

("ageing"[MeSH Terms] OR "ageing"[All Fields]) AND ("diabetes mellitus"[MeSH Terms] OR ("diabetes"[All Fields] AND "mellitus"[All Fields]) OR "diabetes mellitus"[All Fields]) yields 8131 results

\section{Ageing and PEM}

("ageing"[MeSH Terms] OR "ageing"[All Fields]) AND ("protein-energy malnutrition"[MeSH Terms] OR ("protein-energy"[All Fields] AND "malnutrition"[All Fields]) OR "protein-energy malnutrition"[All Fields] OR ("protein"[All Fields] AND "energy"[All Fields] AND "malnutrition"[All Fields]) OR "protein energy malnutrition"[All Fields]) yields 363 results 


\section{PEM and TB}

("protein-energy malnutrition"[MeSH Terms] OR ("protein-energy"[All Fields] AND "malnutrition"[All Fields]) OR "protein-energy malnutrition"[All Fields] OR ("protein"[All Fields] AND "energy"[All Fields] AND "malnutrition"[All Fields]) OR "protein energy malnutrition"[All Fields]) AND ("tuberculosis"[MeSH Terms] OR "tuberculosis"[All Fields] yields 91 results

\section{BMI and TB}

BMI[All Fields] AND TB[All Fields] yields 2666 results.

\section{Treatment of latent TB in ageing population with DM} ("therapy"[Subheading] OR "therapy"[All Fields] OR "treatment"[All Fields] OR "therapeutics"[MeSH Terms] OR "therapeutics"[All Fields]) AND ("latent tuberculosis"[MeSH Terms] OR ("latent"[All Fields] AND "tuberculosis"[All Fields]) OR "latent tuberculosis"[All Fields])) AND ("ageing"[MeSH Terms] OR "ageing"[All Fields])] yields 19 results

\section{Diabetes mellitus and multi drug resistant TB} ("diabetes mellitus"[MeSH Terms] OR ("diabetes"[All Fields] AND "mellitus"[All Fields]) OR "diabetes mellitus"[All Fields]) AND multi [All Fields] AND ("drug resistance"[MeSH Terms] OR ("drug"[All Fields] AND "resistance"[All Fields]) OR "drug resistance"[All Fields] OR ("drug"[All Fields] AND "resistant"[All Fields]) OR "drug resistant"[All Fields]) AND TB. [All Fields] yields 19 results

\section{Diabetes mellitus and multi-drug resistant TB treatment} ("diabetes mellitus"[MeSH Terms] OR ("diabetes"[All Fields] AND "mellitus"[All Fields]) OR "diabetes mellitus"[All Fields]) AND multi[All Fields] AND ("drug resistance"[MeSH Terms] OR ("drug"[All Fields] AND "resistance"[All Fields]) OR "drug resistance"[All Fields] OR ("drug"[All Fields] AND "resistant"[All Fields]) OR "drug resistant"[All Fields]) AND TB[All Fields] AND ("therapy"[Subheading] OR "therapy"[All Fields] OR "treatment"[All Fields] OR "therapeutics"[MeSH Terms] OR "therapeutics"[All Fields]) yields 15 results

\section{DM and PEM}

"diabetes mellitus"[MeSH Terms] OR ("diabetes"[All Fields] AND "mellitus"[All Fields]) OR "diabetes mellitus"[All Fields]) AND ("protein-energy malnutrition"[MeSH Terms] OR ("protein-energy"[All Fields] AND "malnutrition"[All Fields]) OR "protein-energy malnutrition"[All Fields] OR ("protein"[All Fields] AND "energy"[All Fields] AND "malnutrition"[All Fields]) OR "protein energy malnutrition"[All Fields]) yields 164

Bibliographic search included WHO policy papers, personal communication, original articles and review articles written in English, French and Spanish. The following retrieved studies were included: longitudinal studies, randomized controlled trials, reviews or other comparative studies. Case reports were excluded. The included studies were then reviewed by two authors, and major findings reported. No ethical approval was required as this is a comprehensive paper without primary data collection.

\section{Results}

Of the studies retrieved from the above-mentioned electronic database, 13 epidemiological studies and 6 (systematic reviews)/meta-analyses were included in this review. They are summarized in the Table 1 below:

The studies included in this review revealed the following outcomes:

\section{Synergistic effects between TB, immunosenescence and DM}

Immunosenescence and DM act synergistically to limit macrophage activation, which in turn decreases IL 12 and consequently IFN gamma, which is believed to play a central role in CMI against intracellular infection primarily by acting on Natural Killer (NK) and T cells. This is achieved through the following mechanisms:

\section{Mononuclear phagocytes}

Activated mononuclear phagocytes stimulate granuloma formation in response to infection. As humans age, the macrophage capacity for phagocytosis diminishes, which is why the oxidative burst is compromised in elderly persons [30]. In a study involving TB patients, alveolar macrophages were less activated and had lower hydrogen peroxide production in those with DM comorbidity [31].

Additionally, in aged individuals the up-regulation of the major histocompatibility complex (MHC) class I and II expression as well as the antigen presentation capacity are reduced in dendritic cells, [32] which as a corollary diminishes interleukin 2 production and reduces T-cell proliferation. DM has been shown to hamper receptorbound material, [33] which further limits the role of antigen-presenting cells in lymphocyte activation by preventing the phagocytes from binding and internalizing the antigen, for processing and presentation via their $\mathrm{FC}_{\mathrm{C}}$ receptors.

\section{Natural Killer (NK) cells}

It is well known that in elderly humans NK cells show diminished cytotoxic capacity on a 'per cell' basis [34]. Other aspects of NK cell function, such as the secretion of IFN- $\gamma$ in response to IL-2 and IL 12 are also compromised in the aging population [35]. The decrease in IFN- $\gamma$ produced by NK cells is further emphasized in individuals with concomitant DM. 
Table 1 Table summarizing the findings of the studies used in this review

\begin{tabular}{|c|c|c|c|c|c|}
\hline $\begin{array}{l}\text { First } \\
\text { author }\end{array}$ & $\begin{array}{l}\text { Year of } \\
\text { publication }\end{array}$ & Study design and sample size & $\begin{array}{l}\text { Main exposure(s) of } \\
\text { interest }\end{array}$ & $\begin{array}{l}\text { Main outcome(s) } \\
\text { of interest }\end{array}$ & Main results and Remarks \\
\hline Peleg AY & 2007 & Literature review & Glycaemic control & $\begin{array}{l}\text { Risk of common } \\
\text { community } \\
\text { acquired infections }\end{array}$ & $\begin{array}{l}\text { Further research is needed to } \\
\text { improve understanding of the } \\
\text { role of diabetes and glycaemic } \\
\text { control in the pathogenesis and } \\
\text { management of community and } \\
\text { hospital acquired infections }\end{array}$ \\
\hline Leung CC & 2008 & $\begin{array}{l}\text { Cohort study } 42,116 \text { clients } \\
\text { aged } 65 \text { years or more, }\end{array}$ & Diabetes mellitus & $\mathrm{TB}$ & $\begin{array}{l}\text { Among diabetic subjects, higher } \\
\text { risks of active, culture-confirmed, } \\
\text { and pulmonary but not } \\
\text { extrapulmonary tuberculosis were } \\
\text { observed, with baseline hemoglobin } \\
\text { A1c } \geq 7 \% \text { (vs. }<7 \% \text { ) }\end{array}$ \\
\hline $\begin{array}{l}\text { Dick } \\
\text { Menzies }\end{array}$ & 2011 & Review article & LTBI & $\mathrm{TB}$ & $\begin{array}{l}\text { LTBI therapy should be given only } \\
\text { to those with positive tests for LTBI. } \\
\text { Underutilized, particularly in LMIC }\end{array}$ \\
\hline $\begin{array}{l}\text { Matthew J. } \\
\text { Magee }\end{array}$ & 2014 & cohort of 1366 adult patients & DM & MDR TB & $\begin{array}{l}\text { DM did not impact culture } \\
\text { conversion rates in a clinically } \\
\text { meaningful way, but smoking did. }\end{array}$ \\
\hline Holt PR & 2001 & Review/Perspective & Elderly population & Malabsorption & $\begin{array}{l}\text { Nutrition may be compromised } \\
\text { rapidly by the reduction in food } \\
\text { intake or malabsorption that } \\
\text { accompanies many of the } \\
\text { conditions that cause diarrhea } \\
\text { in the elderly }\end{array}$ \\
\hline $\begin{array}{l}\text { Cruz- } \\
\text { Hervert LP }\end{array}$ & 2012 & $\begin{array}{l}\text { Cross sectional study of } 893 \\
65 \text { years of age or older. }\end{array}$ & 65 years of age or older & $\begin{array}{l}\text { Clinical and } \\
\text { epidemiological } \\
\text { consequences of } \\
\text { pulmonary } \\
\text { tuberculosis }\end{array}$ & $\begin{array}{l}\text { Untimely and difficult diagnosis } \\
\text { and a higher risk of poor outcomes } \\
\text { even after treatment completion } \\
\text { emphasize the need for specific } \\
\text { strategies in this vulnerable group. }\end{array}$ \\
\hline $\begin{array}{l}\text { J. Peter } \\
\text { Cegielski }\end{array}$ & 2012 & $\begin{array}{l}\text { Cohort 1982-1992 of 14,189 } \\
\text { adults }\end{array}$ & BMI & TB & $\begin{array}{l}\text { Population's nutritional profile is } \\
\text { an important determinant of TB } \\
\text { incidence. }\end{array}$ \\
\hline Nyadzayo & $\begin{array}{l}2014 \text { (still } \\
\text { in press) }\end{array}$ & Cohort study 410 adults & TB & $\begin{array}{l}\text { Recovery from } \\
\text { moderate } \\
\text { malnutrition }\end{array}$ & $\begin{array}{l}\text { Moderately malnourished adults are } \\
\text { less likely to recover their nutritional } \\
\text { status compared to non-TB patients } \\
\text { when under supplementary treatment }\end{array}$ \\
\hline $\begin{array}{l}\text { Kurbatova, } \\
\text { E. V }\end{array}$ & 2012 & $\begin{array}{l}\text { Cohort study of } 1416 \text { adults } \\
\text { in } 5 \text { countries }\end{array}$ & $\begin{array}{l}\text { predictors of initial } \\
\text { sputum culture } \\
\text { conversion in MDR TB } \\
\text { treatment }\end{array}$ & & $\begin{array}{l}\text { Lower but not significant unadjusted } \\
\text { rate of sputum culture conversion } \\
\text { among patients with DM }\end{array}$ \\
\hline $\begin{array}{l}\text { Matthew J. } \\
\text { Magee }\end{array}$ & 2014 & $\begin{array}{l}\text { Cohort study of 1,366 adult } \\
\text { patients in Georgia }\end{array}$ & $\begin{array}{l}\text { MDR TB treatment in } \\
\text { DM patients }\end{array}$ & $\begin{array}{l}\text { culture conversion } \\
\text { among patients } \\
\text { with multidrug- } \\
\text { resistant (MDR)-TB }\end{array}$ & $\begin{array}{l}\text { In adjusted analyses, DM did not } \\
\text { impact culture conversion rates in } \\
\text { a clinically meaningful way }\end{array}$ \\
\hline $\begin{array}{l}\text { María } \\
\text { Eugenia } \\
\text { Jiménez- } \\
\text { Corona }\end{array}$ & 2013 & $\begin{array}{l}\text { Cohort study of } 1262 \text { patients } \\
\text { with pulmonary TB in Mexico }\end{array}$ & Patients with DM & $\begin{array}{l}\text { clinical } \\
\text { consequences of } \\
\text { pulmonary } \\
\text { tuberculosis }\end{array}$ & $\begin{array}{l}\text { Patients with DM and pulmonary } \\
\text { TB had more severe clinical } \\
\text { manifestations, delayed sputum } \\
\text { conversion, a higher probability of } \\
\text { treatment failure and recurrence }\end{array}$ \\
\hline $\begin{array}{l}\text { Meghan A } \\
\text { Baker }\end{array}$ & 2011 & $\begin{array}{l}\text { Systematic review and } \\
\text { meta-analysis. }\end{array}$ & $\begin{array}{l}\text { quantitative summary } \\
\text { evidence for the impact } \\
\text { of diabetes on } \\
\text { tuberculosis outcomes }\end{array}$ & & $\begin{array}{l}\text { DM increases the risk of treatment } \\
\text { failure and death combined, death } \\
\text { and relapse among patients with } \\
\text { tuberculosis. }\end{array}$ \\
\hline $\begin{array}{l}\text { Christie Y } \\
\text { Jeon }\end{array}$ & 2008 & $\begin{array}{l}13 \text { observational studies } \\
\text { ( } n=1,786,212 \text { participants) } \\
\text { with } 17,698 \text { TB cases }\end{array}$ & Patients with DM & Active TB disease & $\begin{array}{l}\text { Meta-analysis shows that DM } \\
\text { increases the risk of TB, regardless } \\
\text { of different study designs, } \\
\text { background TB incidence or } \\
\text { geographic region of the study. }\end{array}$ \\
\hline $\begin{array}{l}\text { Stevenson } \\
\mathrm{CR}\end{array}$ & 2007 & Review & Patients with DM & Active TB disease & $\begin{array}{l}\text { All studies identified statistically } \\
\text { significant associations, with a }\end{array}$ \\
\hline
\end{tabular}


Table 1 Table summarizing the findings of the studies used in this review (Continued)

\begin{tabular}{|c|c|c|c|c|c|}
\hline & & & & & $\begin{array}{l}\text { 1.5- and 7.8-fold increase in risk } \\
\text { or odds of TB in diabetic patients. } \\
\text { Inadequate adjustment of } \\
\text { potential major confounders. }\end{array}$ \\
\hline Nijland HM & 2006 & $\begin{array}{l}1 \text { prospective pharmacokinetic } \\
\text { study }(n=17 \text { adult patients }\end{array}$ & $\begin{array}{l}\text { Patients with TB-DM } \\
\text { comorbidity }\end{array}$ & $\begin{array}{l}\text { Effect on plasma } \\
\text { rifampicin levels }\end{array}$ & $\begin{array}{l}\text { Study showed } 53 \% \text { lower rifampicin } \\
\text { exposure }\left(\mathrm{AUC}_{0-6} \text { h) in TB-DM }\right. \\
\text { patients, compared to TB only } \\
\text { patients. }\end{array}$ \\
\hline $\begin{array}{l}\text { Meghan A } \\
\text { Baker }\end{array}$ & 2012 & Prospective study & Patients with DM & $\begin{array}{l}\text { Active } T B \text { and } \\
\text { severe } T B\end{array}$ & $\begin{array}{l}\text { The risk of developing tuberculosis } \\
\text { increased among those with } \\
\text { increasing diabetes severity. }\end{array}$ \\
\hline $\begin{array}{l}\text { Brendan K. } \\
\text { Podell, }\end{array}$ & 2012 & $\begin{array}{l}60 \text { guinea pigs were randomly } \\
\text { assigned to Mtb infected and } \\
\text { sucrose-fed ( } n=20) \text {, Mtb infected } \\
\text { and water-fed ( } n=20 \text { ), uninfected } \\
\text { and sucrose-fed (sucrose control, } \\
n=10 \text { ) and uninfected and } \\
\text { water-fed (uninfected control, } \\
n=10 \text { ). }\end{array}$ & Hyperglycaemia & $\begin{array}{l}\text { Severity of } \\
\text { tuberculosis infection } \\
\text { in non-diabetic } \\
\text { guinea pigs }\end{array}$ & $\begin{array}{l}\text { The exacerbation of insulin } \\
\text { resistance and hyperglycaemia by } \\
\text { Mtb infection alone may explain } \\
\text { why TB is more severe in diabetics } \\
\text { with poorly controlled } \\
\text { hyperglycaemia compared to non- } \\
\text { diabetics and patients with properly } \\
\text { controlled blood glucose levels. }\end{array}$ \\
\hline $\begin{array}{l}\text { J. Peter } \\
\text { Cegielski }\end{array}$ & 2012 & $\begin{array}{l}\text { A prospective study of } 13,419 \\
\text { adults from } 25 \text { to } 72 \text { years of age }\end{array}$ & $\begin{array}{l}\text { different levels of } \\
\text { nutritional status }\end{array}$ & Incident cases of TB & $\begin{array}{l}\text { Population's nutritional profile is an } \\
\text { important determinant of TB } \\
\text { incidence, after controlling for } \\
\text { socio-economic factors, excess } \\
\text { alcohol consumption, smoking, } \\
\text { and DM }\end{array}$ \\
\hline $\begin{array}{l}\text { Yung-Feng } \\
\text { Yen }\end{array}$ & 2016 & $\begin{array}{l}\text { Population-Based Follow-Up } \\
\text { Study of } 1608 \text { patients }\end{array}$ & $\begin{array}{l}(<18.5) \text {, normal } \\
(18.5-24.9) \text {, and } \\
\text { overweight }(\geq 25) \text {. }\end{array}$ & $\begin{array}{l}\text { TB treatment } \\
\text { outcome }\end{array}$ & $\begin{array}{l}\text { Insufficient body weight was } \\
\text { associated with higher risks of } \\
\text { TB-specific and non-TB-specific } \\
\text { mortality during TB treatment, } \\
\text { particularly in male patients. }\end{array}$ \\
\hline
\end{tabular}

\section{$T$ lymphocytes}

As humans age, the thymus naturally atrophies and the ability of stem cells to undergo clonal proliferation declines. This further emphasizes the reduced secretion of IL IFN gamma by the macrophages and NK in ageing individuals with DM. The inability to produce adequate numbers of mature $\mathrm{T}$ lymphocytes compromises the ability of elderly individuals to respond effectively to infections.

As $\mathrm{T}$ cells age, they also lose their capacity to produce and respond to IL-2 and IL 12 as major inducers of Th1 type responses, resulting in increased susceptibility to bacterial and viral infections and neoplasias among elderly persons, compared to young adults [36]. An additional synergistic factor is the impaired host resistance in individuals with DM. Namely, lymphocyte proliferation in response to phytohaemagglutinin has been found to be weak in patients with poorly controlled DM [37].

Resistance to mycobacterial infections is mediated largely by $\mathrm{T}$ helper type 1 (Th1) cells and their cytokines, whilst Th2 cells and their cytokines correlate with disease susceptibility and pathology in TB [38]. Whilst Th1 cytokines induces Th1 activity and block Th2 activity, $[39,40]$ Th2 cytokines promote Th2 activity while inhibiting Th1 activity [41]. The decrease in Th1:Th2 ratio may be of great importance in age-related immune changes, since Th1 mainly induces maturation and activation of the cytotoxic $\mathrm{T}$ lymphocytes which decrease with ageing, [42] while Th2 induces increased B lymphocyte immunoglobulin production which increases with ageing [43]. A recent study showed that diabetic TB patients had lower Th1:Th2 cytokine ratios and a higher Th2 bias. Also, the concentration of IL-4 alone was significantly higher in diabetic TB patients compared to non-diabetic TB patients and healthy subjects. As higher concentration of IL-4 is also found in aged individuals due to dysregulation between Th1 and Th2, [44] this synergistic elevation in IL-4 secretion may contribute to increased pathogenesis in diabetic TB patients because IL-4 impairs anti-microbial activity of infected cells and increases availability of iron to intracellular M. tuberculosis.

Elderly DM patients also show an altered $\mathrm{T}$ cytokine production pattern. In aged individuals, lymphocytes produce less IFN- $\gamma$, the main T-helper-1 (Th1) cytokine and the main mediator of protective immunity against TB. DM in aged individuals might further adversely affect T-cell production of interferon $\gamma$, especially in high-glucose conditions. Consequently, $\mathrm{T}$ cell growth, function and proliferation is affected, further compromising effective mononuclear phagocytes and NK cell mediated response to tuberculosis. 
Studies show that when the glycated hemoglobin (HbA1c) is $<8.0 \%$, the proliferative function of CD4 T lymphocytes and their response to antigens remains unimpaired [14]. This was also illustrated in a study of 4690 elderly diabetic patients in Hong Kong: those with haemoglobin A1c $>7 \%$ had a three times higher risk of active tuberculosis compared with those with haemoglobin A1c $<7$ \% (HR 3 - 11; $95 \%$ CI 1.63-5 - 92) [45].

In Taiwan, a prospective study of 17715 Taiwanese persons selected from the general population suggested that the participants' risk of tuberculosis increased as the number of complications of DM increased $(P=0.0016)$, with $>3$-fold risk among those with $\geq 2$ diabetes-related complications (odds ratio, 3.45; 95 \% CI, 1.59-7.50) [46].

Aside from clinically manifested diabetes, a study on infected guinea pigs showed that non-diabetic hyperglycaemia has the potential to significantly worsen active TB, [47] suggesting that inflammation-associated insulin resistance during $T B$ infection may be an additional factor contributing to hyperglycaemia.

\section{Synergistic interactions between TB, ageing and nutritional status}

The lower disease-fighting capacity of the elderly, especially diabetics, which is partly attributable to the deregulation of the immune system and the greater secretion of macrophage pro-inflammatory cytokines in response to antigenic challenge, also leads to greater or longer-lasting body metabolic changes in this population group [48].

Whilst no change was found in $\mathrm{T}$ cell function in very healthy elderly individuals without nutritional deficit,[48] micronutrient deficiency has been shown to further lower immunity by affecting all parameters of CMI, well beyond the effect attributable to the ageing process alone, resulting in increased susceptibility to infectious diseases [49]. The decrease in immune functions strongly correlates with the level of nutritional deficiency, [50] with severely immuno-deficient aged individuals suffering from severe PEM, a condition marked by insufficient protein and calorie intake. Whilst PEM significantly affects innate immunity in the elderly, [51] it chiefly impairs CMI. The resultant atrophy of the thymus [52] reduces the number of circulating $T$ cells, thereby decreasing the effectiveness of the memory response to antigens. PEM is also associated with significantly reduced vaccine antibody responses in the elderly population [53].

The link between body weight and TB has been increasingly reported in scientific literature. A systematic review from 2009 found a strong and consistent loglinear relationship between $\mathrm{TB}$ incidence and BMI across a variety of settings, with different levels of TB burden [54]. In populations where protein insufficiency is common, it may contribute substantially to TB incidence [55]. Namely, a recent large prospective study showed that the population-estimated hazard of developing TB for persons with low BMI $\left(<18.5 \mathrm{~kg} / \mathrm{m}^{2}\right)$ was HR 12.4 (95 \% CI: 5.7, 26.9) greater compared to persons with normal BMI, after controlling for socio-economic factors, excess alcohol consumption, smoking and diabetes mellitus [28].

Also, a cohort study in Taiwan involving patients with a mean age of 64.6 years found that insufficient body weight was associated with higher risks of TB-specific and non-TB-specific mortality during TB treatment, particularly in male patients, after adjusting for age, sex, clinical findings, and comorbidities [56].

\section{Synergistic association between DM and PEM}

Insulin is a strongly anabolic hormone for protein, [57] fat, [58] and glycogen [59] accrual, and deficiency or resistance to insulin may also promote PEM. In addition, comorbidities that diabetic patients are more prone to, such as catabolic events including myocardial infarctions, strokes, infection, ischemic atrophy, $[60,61]$ cutaneous ulcers and gangrene [62] in the extremities increase the likelihood of PEW/ PEM. Studies have demonstrated a higher frequency of protein-wasting in diabetic patients compared to nondiabetic end-stage renal disease patients on maintenance dialysis therapy [63-65].

It is noteworthy that ageing is also associated with decreased capacities to cope with metabolic changes resulting from underfeeding and/or nutritional responses to disease [66]. A personal communication by NyadzayoRossi (who carried out a not yet published cohort study in moderately undernourished adults in Zimbabwe) found that moderately undernourished adult TB patients appear to be at a higher risk of not responding to nutritional treatment compared to those not affected by TB. This finding highlights the need for preventing undernutrition in aged individuals in order to improve TB control, while considering the impact on glycaemic control.

PEM in turn contributes to increased frailty due to depletion of protein body reserves and consequent susceptibility to recurrent TB episodes or other infections in these individuals, already suffering from a lower protection against free radicals. Consequently, PEM is compounded in aged individuals, who suffer from reduced immune responses [49]. Moreover, there is also a possibility of increased TB drug malabsorption in elderly patients [67]. This may be accentuated by PEM, which in turn impairs drug absorption, [68] thereby adding a new dimension to the growing problem of MDR TB. In 2011, a meta-analysis estimated that DM patients have a risk ratio (RR) for the combined outcome of failure and 
death of 1.69 (95 \% CI, 1.36 to 2.12) and an increased risk of relapse (RR, 3.89; $95 \% \mathrm{CI}, 2.43$ to 6.23) after TB treatment [69]. Several studies have reported a high prevalence of DM among patients with MDRTB, [70-72] including an association between DM and MDR-TB after adjusting for confounding factors [73]. However, 4 studies in disparate settings showed no significant increased risk [74-76].

According to WHO estimates, less than $50 \%$ of all cases worldwide are currently diagnosed and treated [77]. Furthermore, due to compromised immunity, such as HIV infection, atypical clinical and radiological features in elderly individuals with DM and PEM as well as false negative tuberculin reactions may be very frequent [78]. A recent study underscored how untimely and difficult diagnosis, along with a higher risk of poor outcomes even after treatment completion emphasizes the need to devise specific strategies for this vulnerable group [79].

\section{TB drug management in diabetic patients}

Diabetes negatively affects TB drug treatment, especially in patients with poor glycaemic control, which may be attributed to altered drug pharmacokinetics in DM. DM affects protein, lipid and carbohydrate metabolism as well as various aspects of pharmacokinetics. These include changes in absorption for several drugs administered via the subcutaneous and intramuscular route, as well as the oral route due to disordered gastric emptying (generally abnormally slow in 30-50 \% DM patients, also slower during hyperglycaemia and accelerated during hypoglycaemia) [80]. Furthermore, the impact of DM on enzymes/transporters involved in drug biotransformation, as well as the reduction of plasma protein binding and displacement of drugs from their protein binding sites (due to higher circulating amount of free fatty acids in DM) [76] also affects drug pharmacokinetics. A recent study on TB showed that disease progression in guinea pigs with impaired glucose tolerance was similar to that of non-diabetic controls in the early stages of infection but got more severe by day 90 [81]. Drug toxicity risk may be higher due to excessive drug accumulation in the body, as a result of diabetic nephropathy.

A study involving 17 Indonesian patients with TB-DM comorbidity found $53 \%$ lower plasma concentrations of rifampicin in these patients, compared to patients with $\mathrm{TB}$ only. These pharmacokinetic changes have been associated with clinical failure and acquired drug resistance [82]. These observations are congruent with those of a study from Mexico published in 2013 which reported that the proportion of TB patients on first line TB therapy who converted sputum cultures to negative $\geq 60$ days of treatment was significantly greater in patients with DM (45.9\%) compared to those without DM (37.2 \%) [83].

\section{MDR TB drug management in diabetic patients}

The influence of DM on MDR-TB patient outcomes is understudied [84]. Findings from a study on MDR-TB in 2012 involving diabetic patients from five countries, reported a lower non-significant univariate rate ratio (HR 0.76, 95 \% CI 0.54-1.06) of sputum culture conversion among patients with DM [85]. These findings are congruent with those of a recent cohort study of adult pulmonary MDR-TB patients from Georgia, according to which, after adjusting for important confounding factors, the rate of sputum culture conversion and the risk of poor treatment outcome was similar in MDR-TB patients with and without DM, adjusted HR estimate $(0.95$, $95 \%$ CI 0.71-1.28).

A bi-directional relationship has also been observed, as ethionamide or protionamide have been shown to make DM management in patients undergoing treatment with the above drugs more difficult [66].

\section{Research gaps}

Association between DM and PEM in the elderly population

Randomized clinical trials exploring the optimal methods of monitoring for PEM as well as prevention and treatment of these disorders in diabetic elderly patients are clearly needed.

\section{Association between DM and MDR TB}

At a biological level, there is a need of a better understanding of diabetes-related immunopathogenic mechanisms reinforcing immunosenescence, and mechanisms by which DM may lead to MDR TB.

\section{The impact of DM on TB and MDR TB treatment outcomes}

Despite extensive research efforts to elucidate the effects of DM on pharmacokinetics and pharmacodynamics and the significant progress made in this area, the available information is nonetheless insufficiently clear. Additional clinical studies are needed to fully unravel the clinical significance of these effects. DM - mediated changes in the pharmacokinetics of a particular drug must not be generalized to include other drugs, as changes are drug-specific.

Biological mechanisms potentially contributing to TB and MDR TB treatment failure as well as those interfering with glucose control during rifampicin and ethionamide therapy must be elucidated in conjunction with further epidemiological studies exploring the impact of $\mathrm{DM}$ on both first line and second line treatments.

In contrast to experimental animal models, DMrelated effects on pharmacological properties of drugs in human subjects have not been sufficiently elaborated. Further larger prospective research aimed at understanding the diabetes-mediated changes as well 
as the sources of the variability is required to help optimize drug management and improve clinical outcomes in DM patients [86].

Furthermore, in order to avoid future discrepancies between individual clinical studies, as well as between ex vivo and clinical studies on this issue, due attention should be paid to adequate selection of test subjects, the type, severity and duration of the disease, histopathological characteristics, as well as other important factors such as medication use, protein intake, age, sex and obesity.

\section{Association between low BMI and TB}

Although a large prospective study found that persons with low BMI $\left(<18.5 \mathrm{~kg} / \mathrm{m}^{2}\right)$ are at higher risk of developing active TB compared to those with normal BMI, after controlling for socio-economic factors, excess alcohol consumption, smoking, and diabetes mellitus, it may also be useful to adjust for micronutrient deficiencies. Also, this area of research would benefit from a case control study, wherein active TB elderly patients are compared to non active TB patients in terms of BMI, using the WHO BMI categorization [87]: $<16=$ severe malnutrition, $16-16.99=$ moderate malnutrition, $17-$ $18.49=$ mild malnutrition; $18.5-24.99=$ normal weight , 25-29.99 = overweight; $\geq 30=$ obese.

Furthermore, it may also be necessary to explore more thoroughly whether TB patients have more difficulties in recovering from malnutrition compared to non-TB patients, a recommendation which is also stipulated in the WHO nutritional guidelines for TB [88].

\section{Clinical diagnostic algorithm for elderly patients with DM}

Reducing the duration of infectiousness will require establishment of an appropriate clinical diagnostic algorithm and adaptation of clinical guidelines to address elderly patients with DM. Clinical research is warranted to establish a clinical diagnostic algorithm as well as clinical management guidelines targeting this population.

\section{Prevention of active $T B$}

Twenty randomized trials involving treatment of latent TB infection (LTBI) to prevent active TB in more than a dozen countries demonstrated that isoniazid (INH) administered for at least 6 months in persons with LTBI reduced subsequent TB incidence by 25 to $92 \%$ [89]; the differences were mainly attributed to variation in treatment completion. In the elderly population with $\mathrm{DM}$ and PEM, the effectiveness of an INH regimen still needs to be determined, along with exploring its high potential for hepatotoxicity and the pharmacoepidemiology of INH interaction with other drugs.

\section{Bi-directionality of TB and DM}

Studies have shown that TB can even cause DM in those not previously known to be diabetic, with TB patients showing higher rates of glucose intolerance than community controls $[33,90,91]$. This may not only lead to a global explosion of TB cases, but also DM cases. Furthermore, determining the bi-directionality of $\mathrm{TB}$ and $\mathrm{DM}$ and the potential of DM to fuel not only a TB, but potentially a MDR TB epidemic will need to be investigated.

\section{Discussion}

At a global level, the lethal cocktail of ageing population with PEM, latent TB and concomitant diabetes mellitus sets the stage for increased TB transmission that may fuel a TB epidemic and possibly a MDR TB epidemic.

Reducing TB transmission in low, middle and high income settings will require a multipronged approach. In middle and higher income countries, the increasing number of people residing in nursing and chronic disease facilities places residents at greater risk for developing active TB than elderly persons living in the community, with the potential of spilling over within the community. In low-income countries, higher life expectancy combined with an already high prevalence of PEM may fuel an unprecedented TB and possibly an MDR TB epidemic.

This begs for an integrative framework for enhanced TB control and prevention among aged diabetics as well as a stringent screening of glycaemic responses in TB patients at the time of diagnosis, even if diagnostic criteria for diabetes are not met $[84,92]$ This integrative framework should be tailored to the contexts of industrialized and middle - income countries. To this end, the working definition of "old" must first be established per setting. Most industrialized nations have accepted the chronological age of 65 years as a definition of 'elderly' or older person, [93] whilst in sub-Saharan Africa a MDS/WHO established the age of 50 years as a working definition of "old." This will be all the more relevant for low- to middle-income countries, including India and China, which have the highest burden of $\mathrm{TB}$ and are experiencing the fastest increase in diabetes prevalence [16].

As an adjunct, PEM management should be strengthened. PEM management research must also encompass a better appreciation of the nutritional status of the elderly population, especially in resource-poorer countries. In addition, another salient area of research would be to explore the protective effect of higher BMI in preventing development of active TB or improving disease outcome. If these observations are confirmed, policies regarding isoniazid preventive treatment could be revisited because the potential benefit would be much lower among 
elderly persons with medium to high BMI. Moreover, WHO guidelines for TB nutritional support must establish a calorie intake threshold for aged diabetic patients.

\section{Conclusion}

The still poorly elucidated tripartite association involving TB, PEM, and DM in the ageing population threatens to place a major burden on the public health system. A number of epidemiological and clinical gaps must be addressed to curb transmission. Enhanced PEM management, especially in resource-poorer settings, the development of a clinical diagnostic algorithm as well as clinical guidelines for this population are urgently needed. To thwart an explosion of TB and potential MDR TB and DM epidemics, the transmission dynamics should be examined.

\section{Abbreviations}

BMI, Body Mass Index; DM, Diabetes Mellitus; IFN- $\gamma$, Interferon gamma; LTBI, Latent TB infection; MDR TB, Multi drug resistance TB; PEM, Protein Energy Malnutrition; TB, Tuberculosis

\section{Acknowledgement}

Dr S. Siddhartha, Dr R. Menon, Dr J Shaikh, for their intellectual guidance.

\section{Funding}

This research was not funded.

\section{Availability of data and materials} see Table 1

\section{Authors' contributions \\ SM lead author conceived and drafted the manuscript, searched the literature, summarized the findings, and interpreted the findings. RR searched the literature, interpreted the findings, participated in the revision and validation of the final version of the manuscript. NZ searched the literature, interpreted findings, provided input from a clinical pharmacy perspective and participated in the revision, validation and editing of the final version of the manuscript. LN participated in the revision and validation of the manuscript. AW participated in the revision and validation of the manuscript. ME participated in the conception, revision, and validated the manuscript. All authors read and approved the final manuscript.}

\section{Competing interests}

The authors declare that they have no competing interests.

\section{Consent for publication}

Not applicable.

\section{Ethics approval and consent to participate}

Not applicable.

\begin{abstract}
Author details
${ }^{1}$ International Centre for Reproductive health, Ghent University, LSHTM Alumni, Ghent, Belgium. ${ }^{2}$ CDC Foundation, Atlanta, USA. ' ${ }^{3}$ LSHTM Alumni, Beirut, Lebanon. ${ }^{4}$ Department of Social and Preventive Medicine, Laval University-Faculty of Medicine, Quebec, Canada. ${ }^{5}$ Department of Epidemiology, Biostatistics, and Occupational Health, McGill University, Montreal, Canada. ${ }^{6}$ Department of Clinical Pharmacy, Saints Cyril and Methodius University of Skopje (Alumni), Skopje, Republic of Macedonia. ${ }^{7}$ Médecins Sans Frontières, Paris, France.
\end{abstract}

Received: 1 October 2015 Accepted: 15 July 2016

Published online: 26 July 2016

\section{References}

1. WHO. Latent Tuberculosis Infection (LTBI). 2015.
2. Restrepo BI, Camerlin AJ, Rahbar MH, Wang W, Restrepo MA, Zarate I, et al. Cross-sectional assessment reveals high diabetes prevalence among newlydiagnosed tuberculosis cases. Bull World Health Organ. 2011;89:352-9.

3. WHO. Global tuberculosis report 2013. Geneva: World Health Organization; 2013.

4. Hu FB, Manson JE, Stampfer MJ, et al. Diet, lifestyle, and the risk of type 2 diabetes mellitus in women. N Engl J Med. 2001;345:790-97.

5. Mozaffarian D, Kamineni A, Carnethon M, Djousse L, Mukamal KJ, Siscovick D. Lifestyle risk factors and new-onset diabetes mellitus in older adults: the cardiovascular health study. Arch Intern Med. 2009;169:798-807.

6. WHO. Stop TB: Tuberculosis and Diabetes. 2011.

7. International Diabetes Foundation. Diabetes atlas. 4th ed. Brussels: International Diabetes Foundation; 2009.

8. Wild S, Roglic G, Green A, Sicree R, King H. Global prevalence of diabetes: estimates for the year 2000 and projections for 2030. Diabetes Care. 2004; 27:1047-53.

9. King H, Aubert RE, Herman WH. Global burden of diabetes, 1995-2025: prevalence, numerical estimates, and projections. Diabetes Care. 1998;21: $1414-31$.

10. Mustafa AS. Recombinant and synthetic peptides to identify Mycobacterium tuberculosis antigens and epitopes of diagnostic and vaccine relevance. Tuberculosis (Edinb). 2005;85:367-76.

11. Al-Attiyah R, Madi N, El-Shamy AS, Wiker H, Andersen P, Mustafa AS. Cytokine profiles in tuberculosis patients and healthy subjects in response to complex and single antigens of Mycobacterium tuberculosis. FEMS Immunol Med Microbiol. 2006;47:254-61.

12. Flynn J. Immunology of tuberculosis and implications in vaccine development. Tuberculosis. 2004;4:93-101.

13. Geerlings SE, Hoepelman AI. Immune dysfunction in patients with diabetes mellitus (DM) FEMS. Immunol Med Microbiol. 1999;26:256-65.

14. Peleg AY, Weerarathna T, McCarthy JS, Davis TM. Common infections in diabetes: Pathogenesis, management and relationship to glycaemic control. Diabetes Metab Res Rev. 2007;23:3-13.

15. Harries AD, Lin Y, Satyanarayana S, Lönroth K, Li L, Wilson N, et al. The looming epidemic of diabetes-associated tuberculosis: learning lessons from the HIV-associated tuberculosis. Inter J Tuberc Lung Dis. 2011;15:1436-45.

16. Stevenson CR, Forouhi NG, Roglic G, et al. Diabetes and tuberculosis: the impact of the diabetes epidemic on tuberculosis incidence. BMC Public Health. 2007;7:234

17. Jeon CY, Murray MB. Diabetes mellitus increases the risk of active tuberculosis: a systematic review of 13 observational studies. PLoS Med. 2008;5, e152.

18. Stevenson CR, Critchley JA, Forouhi NG, Roglic G, Williams BG, et al. Diabetes and the risk of tuberculosis: a neglected threat to public health. Chronic IIIn. 2007;3:228-45.

19. Swai $A B$, McLarty DG, Mugusi F. Tuberculosis in diabetic patients in Tanzania. Trop Doct. 1990;20:147-50.

20. Media Centre, United Nations of Population Fund, ageing http://www. unfpa.org/ageing Accessed 20 Jul 2016.

21. WHO. Health statistics and information system. 2015.

22. Yoshikawa TT. Tuberculosis in ageing adults. J Am Geriatr Geriatr Soc. 1992; 40:178-87.

23. Pedrazzini T, Hug K, Louis JA. Importance of L3T4+ and Lyt2+ cells in the immunologic control of infection with Mycobacterium bovis strain bacillus Calmette Guerin in mice. Assessment by elimination of T cells subsets in vivo. J Immunnol. 1987;139:2032-7.

24. Akner G, Cederholm T. Treatment of protein-energy malnutrition in chronic nonmalignant disorders. Am J Clin Nutr. 2001;74:6-24.

25. Chandra RK, Gupta S, Singh H. Inducer and suppressor T cell subsets in protein-energy malnutrition. Analysis by monoclonal antibodies. Nutr Res. 1982:2(1):21-6.

26. Lönnroth K, Castro KG, Chakaya JM, et al. Tuberculosis control and elimination 2010-50: cure, care, and social development. Lancet. 2010; 375(9728):1814-29.

27. Maher D, Raviglione M. Global epidemiology of tuberculosis. Clin Chest Med. 2005;26(2):167-82.

28. Cegielski JP, McMurray DN. The relationship between malnutrition and tuberculosis: evidence from studies in humans and experimental animals. Int J Tuberc Lung Dis. 2004;8(3):286-98.

29. McMurray DN, Cegielski JP. The influence of nutrition on the risk and outcomes of tuberculosis. In: Academy of Science of South Africa 
Consensus Panel on Nutrition, HIV/ AIDS, and TB, editor. HIV/AIDS, TB, and Nutrition: Scienti fic Inquiry Into the Nutritional Influences on Human Immunity With Special Reference to HIV Infection and Active TB in South Africa. Pretoria: Academy of Science of South Africa; 2007. p. 153-69.

30. Gomez CR, Boehmer ED, Kovacs EJ. The ageing innate immune system. Curr Opin Immunol. 2005;17:457-62

31. Wang CH, Yu CT, Lin HC, Liu CY, Kuo HP. Hypodense alveolar macrophages in patients with diabetes mellitus and active pulmonary tuberculosis. Tuber Lung Dis. 1999;79:235-42.

32. Grewe M. Chronological ageing and photoageing of dendritic cells. Clin Exp Dermatol. 2001;26:608-12.

33. Abbras CK. Fc receptor-mediated phagocytosis: abnormalities associated with diabetesmellitus. Clin Immunol Immunopathol. 1991:58:1-17.

34. Rukavina D, Laskarin G, Rubesa G, et al. Age-related decline of perforin expression in human cytotoxic T lymphocytes and natural killer cells. Blood. 1998:92:2410-20

35. Mariani E, Meneghetti A, Neri S, Ravaglia G, Forti P, Cattini L, Facchini A. Chemokine production by natural killer cells from nonagenarians. Eur J Immunol. 2002:32:1524-9.

36. Pawelec G. Immunosenescence: impact in the young as well as the old? Mech Ageing Dev. 1999.

37. MacCuish AC, Urbaniak SJ, Campbell CJ, Duncan L, Irvine WJ. Phytohemagglutinin transformation and circulating lymphocyte subpopulations in insulin-dependent diabetic patients. Diabetes. 1974;23:708-12.

38. Turner J, Gonzalez-Juarrero M, Ellis DL, et al. In vivo IL-10 production reactivates chronic pulmonary tuberculosis in C57BL/6 mice. J Immunol. 2002;169:6343-51.

39. Hsieh C-S, Macatonia SE, Tripp CS, Wolf SF, O'Garra A, Murphy KM. Development of Th1 CD4+ T cells through IL-12 produced by Listeria induced macrophages. Science. 1993;260:547-9.

40. Manetti R, Parronchi P, Giudizi M-G, Piccinni M-P, Maggi E, Trinchieri G, Romagnani S. Natural killer cell stimulatory factor (interleukin 12) induces T helper type (Th1)-specific immune responses and inhibits the development of IL-4 producing Th cells. J Exp Med. 1989;177:1199-204.

41. Swain SL. IL-4 dictates T-cell differentiation. Res Immunol. 1993;144:616-20.

42. Bruley-Roseet M, Payelle B. Deficient tumor specific immunity in old mice: in vivo mediation by suppressor cells, and correction of the defect interleukin 2 by supplementation in vitro but not in vivo. $J$ Immunol. 1987;17:307-12

43. Batory G, Janeso A, Puskas E, Redei A, Lengyei E. Antibody and immunoglobulin levels in aged humans. Arch Gerontol Geriatr. 1984;3:175-88.

44. Pawelec G. Basic Biology and Clinical impact of immunosenecence. volume 13. Elsevier; 2003.

45. Leung CC, Lam TH, Chan WM, et al. Diabetic control and risk of tuberculosis: a cohort study. Am J Epidemiol. 2008;167:1486-94.

46. Baker MA, Lin HH, Chang HY, Murray MB. The risk of tuberculosis disease among persons with diabetes mellitus: a prospective cohort study. Clin Infect Dis. 2012;54:818-25.

47. Podell BK, Ackart DF, Kirk NM, Eck SP, Bell C, Basaraba RJ. Non-Diabetic Hyperglycemia Exacerbates Disease Severity in Mycobacterium tuberculosis Infected Guinea Pigs. Karakousis PC. PLoS One. 2012;7(10):e46824. doi:10. 1371/journal.pone.0046824

48. Cederholm T, Jagren C, Hellstrom K. Outcome of protein-energy malnutrition in elderly medical patients. Am J Med. 1995;98:67-74

49. Lesourd B, Mazari L. Nutrition and immunity in the elderly. Proc Nutr Soc. 1999;58:685-95

50. Chandra RK. Nutrition, regulation of immunity and risk of infection on old age. Immunology. 1989;67:141-7.

51. Lipschitz DA, Udupa KB. Influence of ageing and protein deficiency on neutrophil function. J Gerontol. 1986;41:281-8.

52. Drake VJ. Nutrition and Immunity. Linus Pauling Institute; 2010. http://lpi. oregonstate.edu/mic/micronutrients-health/immunity. Accessed 20 Jul 2016.

53. Chandra RK. Nutritional regulation of immune function at the extremes of life: in infants and in the elderly. In: Malnutrition Determinants and Consequences. New York: Alan R Liss; 1994. p. 245-51.

54. Hanrahan CF, Golub JE, Mohapi L, et al. Body mass index and risk of tuberculosis and death. AIDS (London, England). 2010;24(10):1501-8. doi:10. 1097/QAD.0b013e32833a2a4a.

55. Cegielski JP, Arab L, Cornoni-Huntley J. Nutritional risk factors for tuberculosis among adults in the United States, 1971-1992. Am J Epidemiol. 2012;176:409-22. doi:10.1093/aje/kws007.
56. Yen Y-F, Chuang P-H, Yen M-Y, et al. Association of Body Mass Index With Tuberculosis Mortality: A Population-Based Follow-Up Study. Levin. A, ed. Medicine. 2016;95(1):e2300. doi:10.1097/MD.0000000000002300.

57. Bennet WM, Rennie MJ. Protein anabolic actions of insulin in the human body. Diabet Med. 1991;8:199-207.

58. Ikeoka D, Krusinova E. Insulin resistance and lipid metabolism. Rev Assoc Med Bras. 2009;55:234

59. Golay A, Munger R, Assimacopoulos-Jeannet F, Bobbioni-Harsch E, Habicht F, Felber JP. Progressive defect of insulin action on glycogen synthase in obesity and diabetes. Metabolism. 2002;51:549-53.

60. Racki S, Zaputovic L, Vujicic B, Crncevic'-Orlic' Z, Dvornik Z. Comparison of survival between diabetic and non-diabetic patients on maintenance hemodialysis: a single-centre experience. Diabetes Res Clin Pract. 2007;75: 169-75.

61. Xue JL, Frazier ET, Herzog CA, Collins AJ. Association of heart disease with diabetes and hypertension in patients with ESRD. Am J Kidney Dis. 2005;45: 316-23.

62. Georgopoulos S, Filis K, Vourliotakis G, Bakoyannis C, Papapetrou A, Klonaris C, Papalambros E, Bastounis E. Lower extremity bypass procedures in diabetic patients with end-stage worthwhile? Nephron Clin Pract. 2005;99: c37-41.

63. Malgorzewicz S, Lichodziejewska-Niemierko M, Rutkowski B, LysiakSzydlowska W. Nutritional status and oxidative processes in diabetic and nondiabetic peritoneal dialysis patients. J Ren Nutr. 2004;14:242-7.

64. Pupim LB, Heimburger O, Qureshi AR, Ikizler TA, Stenvinkel P. Accelerated lean body mass loss in incident chronic dialysis patients with diabetes mellitus. Kidney Int. 2005;68:2368-74.

65. Cano NJ, Roth H, Aparicio M, Azar R, Canaud B, Chauveau P, Combe C, Fouque D, Laville M, Leverve XM, French Study Group for Nutrition in Dialysis (FSG-ND). Malnutrition in hemodialysis dia-betic patients: evaluation and prognostic influence. Kidney Int. 2002;62:593-601.

66. World Health Organization. Companion Handbook to the WHO Guidelines for the Programmatic Management of Drug-Resistant Tuberculosis. 2014. http://apps.who.int/iris/bitstream/10665/130918/1/9789241548809_eng.pdf. Accessed 20 Jul 2016.

67. Holt PR. Diarrhea and malabsorption in the elderly. Gastroenterol Clin North Am. 2001;30(2):427-44

68. Gómez F, Ramos Galvan R, Frenk S, Cravioto Muñoz J, Chávez R, Vázquez J. Mortality in second and third degree malnutrition. 1956. Bull World Health Organ. 2000;8:1275-80.

69. Baker MA, Harries AD, Jeon CY, Hart JE, Kapur A, et al. The impact of diabetes on tuberculosis treatment outcomes: A systematic review. BMC Med. 2011:9:81. doi:10.1186/1741-7015-9-81.

70. Singh R, Gothi $D$, Joshi J. Multidrug resistant tuberculosis: Role of previous treatment with second line therapy on treatment outcome. Lung India. 2007:24:54-7. doi:10.4103/0970-2113.44211.

71. Aragon J, Litonjua A, Tupasi T, Quelapio I. Prevalence of type 2 diabetes among multi-drug resistant tuberculosis (MDR-TB) patients seen in Makati Medical Center under the directly observed therapy plus (DOTS PLUS) program. Phil J Internal Medicine. 2003;41:7-10.

72. Garcia F, Solis J, Calderon J, Luque E, Zacarias E. Prevalence of diabetes mellitus and related risk factors in an urban population. Rev Soc Peru Med Interna. 2007:20:90-4.

73. Fisher-Hoch SP, Whitney E, McCormick JB, Crespo G, Smith B, et al. Type 2 diabetes and multidrug-resistant tuberculosis. Scand J Infect Dis. 2008;40: 888-93. doi:10.1080/00365540802342372.

74. Singla R, Khan N. Does diabetes predispose to the development of multidrug-resistant tuberculosis? Chest. 2003;123:308-09.

75. Subhash HS, Ashwin I, Mukundan U, et al. Drug resistant tuberculosis in diabetes mellitus: a retrospective study from south India. Trop Doct. 2003; 33:154-56.

76. Tanrikulu AC, Hosoglu S, Ozekinci T, Abakay A, Gurkan F. Risk factors for drug resistant tuberculosis in southeast Turkey. Trop Doct. 2008;38:91-3.

77. Global tuberculosis control. Surveillance, planning, financing: 2010. (Report No.: WHO/HTM/TB/2006.362). Geneva: World Health Organization; 2010. World Health Organization.

78. Gopalan C. Importance of nutritional factors in tuberculosis. Indian J Tuberculosis. 1957:4:105-12.

79. Cruz-Hervert LP, García-García L, Ferreyra-Reyes L, et al. Tuberculosis in ageing: high rates, complex diagnosis and poor clinical outcomes. Age Ageing. 2012;41(4):488-95. doi:10.1093/ageing/afs028. 
80. Horowitz M, Wishart JM, Jones KL, Hebbard GS. Gastric emptying in diabetes: an overview. Diabet Med. 1996.

81. Podell BK, Ackart DF, Obregon-Henao A, et al. Increased Severity of Tuberculosis in Guinea Pigs with Type 2 Diabetes: A Model of DiabetesTuberculosis Comorbidity. Am J Pathol. 2014;184(4):1104-18. doi:10.1016/j. ajpath.2013.12.015.

82. Nijland HMJ, Ruslami R, Stalenhoef JE, Nelwan EJ, Alisjahbana B, Nelwan RH, van der Ven A, Danusantoso H, Aarnoutse RE, van Crevel R. Exposure to rifampicin is strongly reduced in tuberculosis patients with type 2 diabetes. Clin Infect Dis. 2006.

83. Jimenez-Corona ME, Cruz-Hervert LP, Garcia-Garcia L, Ferreyra-Reyes L, Delgado-Sanchez $G$, et al. Association of diabetes and tuberculosis: impact on treatment and post-treatment outcomes. Thorax. 2013;68:214-20. doi:10.1136/thoraxjnl-2012-201756.

84. Harries AD, Murray MB, Jeon CY, Ottmani SE, Lonnroth $K$, et al. Defining the research agenda to reduce the joint burden of disease from diabetes mellitus and tuberculosis. Trop Med Int Health. 2010;15:659-63. doi:10.1111/ j.1365-3156.2010.02523.

85. Kurbatova EV, Gammino VM, Bayona J, Becerra MC, Danilovitz M, et al. Predictors of sputum culture conversion among patients treated for multidrug-resistant tuberculosis. Int J Tuberc Lung Dis. 2012;16:1335-43. doi:10.5588/ijtld.11.0811.

86. Dostalek M, Akhlaghi F, Puzanovova M. Effect of diabetes mellitus on pharmacokinetic and pharmacodynamic properties of drugs. Clin Pharmacokinet. 2012.

87. WHO Global Database on Body Mass Index an interactive surveillance tool for monitoring nutrition transition http://apps.who.int/bmi/index. jsp?introPage=intro_3.html. Accessed 19 Jul 2016.

88. WHO. Guideline: Nutritional care and support for patients with tuberculosis. Geneva: World Health Organization; 2013.

89. Menzies $\mathrm{D}, \mathrm{Al} \mathrm{JH}, \mathrm{Al} \mathrm{OB}$. Recent developments in treatment of latent tuberculosis infection. Indian J Med Res. 2011;133:257-66.

90. Nichols GP. Diabetes among young tuberculous patients; a review of the association of the two diseases. Am Rev Tuberc. 1957;76:1016-30.

91. Zack MB, Fulkerson LL, Stein E. Glucose intolerance in pulmonary tuberculosis. Am Rev Respir Dis. 1973;108:1164-69.

92. Harries AD, Lonnroth K. Collaborative framework for care and control of tuberculosis and diabetes. Geneva: World Health Organziation Press; 2011.

93. WHO. Health Statistics and Information system Definition of an elderly or older person. 2016. http://www.who.int/healthinfo/survey/ageingdefnolder/ en/. Accessed 20 Jul 2016.

\section{Submit your next manuscript to BioMed Central and we will help you at every step:}

- We accept pre-submission inquiries

- Our selector tool helps you to find the most relevant journal

- We provide round the clock customer support

- Convenient online submission

- Thorough peer review

- Inclusion in PubMed and all major indexing services

- Maximum visibility for your research

Submit your manuscript at www.biomedcentral.com/submit 